\title{
Correction: A dual clustering framework for association screening with whole genome sequencing data and longitudinal traits
}

\author{
Ying Liu', Chien Hsun Huang ${ }^{1}$, Inchi Hu², Shaw-Hwa Lo', Tian Zheng ${ }^{1 *}$ \\ From Genetic Analysis Workshop 18 \\ Stevenson, WA, USA. 13-17 October 2012
}

\section{Correction}

For the previous publication of our article [1], Figure 1 was incorrectly processed as grayscale. We present, here in this correction, the original Figure in full color.

This article has been published as part of BMC Proceedings Volume 8 Supplement 1, 2014: Genetic Analysis Workshop 18. The full contents of the supplement are available online at http://www.biomedcentral.com/bmcproc/ supplements/8/S1.

\section{Authors' details}

'Department of Statistics, Columbia University, New York, NY 10027, USA. ${ }^{2}$ ISOM, Hong Kong University of Science and Technology, Kowloon, Hong Kong.

Published: 24 July 2014

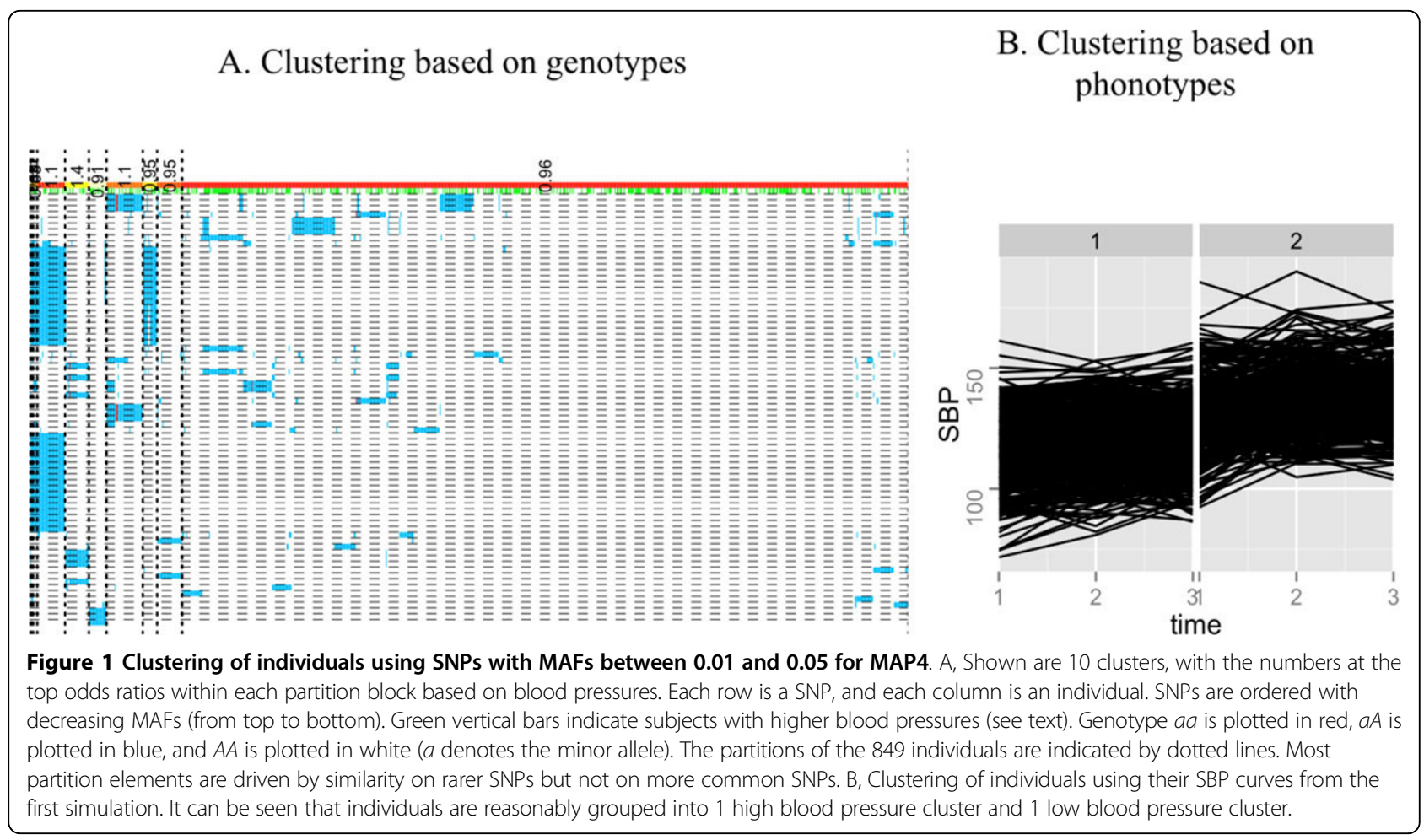

\footnotetext{
* Correspondence: tzheng@stat.columbia.edu

1 Department of Statistics, Columbia University, New York, NY 10027, USA

Full list of author information is available at the end of the article
} 


\section{Reference}

1. Liu Y, Huang $\mathrm{CH}, \mathrm{Hu}$ I, Lo SH, Zheng T: A dual clustering framework for association screening with whole genome sequencing data and longitudinal traits. BMC Proc 2014, 8(Suppl 1):S47.

doi:10.1186/1753-6561-8-S1-S112

Cite this article as: Liu et al.: Correction: A dual clustering framework for association screening with whole genome sequencing data and longitudinal traits. BMC Proceedings 2014 8(Suppl 1):S112.

Submit your next manuscript to BioMed Central and take full advantage of:

- Convenient online submission

- Thorough peer review

- No space constraints or color figure charges

- Immediate publication on acceptance

- Inclusion in PubMed, CAS, Scopus and Google Scholar

- Research which is freely available for redistribution

Submit your manuscript at www.biomedcentral.com/submit

() Biomed Central 